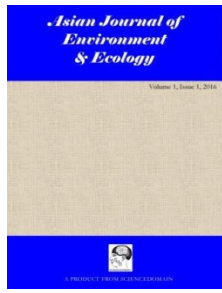

\title{
Community Participation: Panacea for Rural Development Programmes in Rivers State, Nigeria
}

\author{
Ibama Brown $^{1^{*}}$ and Chikagbum Wocha ${ }^{2}$ \\ ${ }^{1}$ Department of Urban and Regional Planning, Rivers State University, Port Harcourt, Nigeria. \\ ${ }^{2}$ Department of Urban and Regional Planning, Ken Saro- Wiwa Polytechnic, Bori, Rivers State,
}

Nigeria.

Authors' contributions

This work was carried out in collaboration between both authors. Author IB designed the study, performed the statistical analysis, wrote the protocol and wrote the first draft of the manuscript. Author CW managed the analyses of the study. Authors IB and CW managed the literature searches. Both authors read and approved the final manuscript.

Article Information

DOI: $10.9734 / A J E E / 2017 / 34076$

Editor(s):

(1) Anthony R. Lupo, Department of Soil, Environmental, and Atmospheric Science, University of Missouri, Columbia, USA.

Reviewers:

(1) Anju Bharti, GGSIP University, India.

(2) Augrey H. Malambo, University of Zambia, Zambia.

Complete Peer review History: http://www.sciencedomain.org/review-history/19588

Original Research Article

Received $12^{\text {th }}$ May 2017

Accepted $31^{\text {st }}$ May 2017

Published $17^{\text {th }}$ June 2017

ABSTRACT

Community participation has been identified as effective driver of rural development in emerging economies while community development committees (CDCs) are key players in implementing rural development programmes in communities. The study aims at assessing the level of participation of communities and community development committees in the provision of public infrastructure in selected communities of Abua/Odual Local Government Area in Rivers. The objectives are to: identify existing mechanism for public participation in rural development process; ascertain the nature and extent of participation in rural development, ascertain the participation level of Community Development Committee (CDC) in implementation of development projects. A cross-sectional study that engaged multistage sampling technique was adopted. Primary and secondary data were collected, analysed and represented with charts, percentages and tables. One hundred (100) respondents were purposively drawn from Otari, Odaga and Omalem communities and stratified sampling was applied to administer questionnaire, only heads of households and members of community development committees formed the respondents. The 
study found out among other things; that the community development committees (CDCs) in the respective communities were effective in the dissemination of information with respect to projects embarked upon by the government to encourage community participation; there is a dearth of information and lack of synergy between the government agencies charged with the responsibility of planning and implementing rural development policies and the beneficiaries of such development; no Local Planning Authorities at the local government areas. The study recommended that members of the CDCs should form part members of planning and implementation committees in their respective communities, immediate establishment of local planning authorities.

Keywords: Community development committee; implementation; infrastructure provision; planning; public.

\section{INTRODUCTION}

In recent times, rural development has been in the front burner of several developmental attempts aimed at improving the quality of life and living standard of the rural areas and the teeming population in developed and developing countries alike. This trend has gradually metamorphosed into a new paradigm shift from the old ways of agro-based economy to modernization of lifestyle and activities which are geared towards upgrading the rural areas. This could be a step in the process of rural development, although $[1,2]$ assert that there is no clear and comprehensive definition of rural development as the definition is scenario specific.

According to [3] the idea of rural development arose from political and social struggles. Rural development has been viewed as a discourse that revolves around the rural area and agriculture but in recent times, it is perceived to be an inclination towards the alienation of farmers and their holdings on one hand and a factor to invigorate agriculture on the other hand [4].

In the early and mid-1990s, several rural development programmes arose across Europe which [5] described as multilevel governance structures that were funded by the European Union. These funded programmes were targeted at trying to reconstitute regional governance structures with emphasis on the development of the rural areas that will be self-sustaining through capacity building, community-based creativities and partnerships [6-8].

The research on the initiatives and the initiatives themselves were engrossed with increasing the level of participation in their all-inclusive nature, characteristics and what was well-defined as 'community' $[8,9,10]$.
Chambers [11] asserts that rural development is a stratagem that enables specific group of people who may be underprivileged in rural areas gain for themselves more of what they need. By implication this assertion most times leads to participation of the rural dwellers. Rural development at this point could be referred to as the process of improving the economic wellbeing and the quality of life of a people domiciled in sparsely populated and comparatively remote areas in any given society. The focus of rural development is directed at finding ways to improve the lives of the rural population which is geared towards encouraging participation. Participation according to [12] is a far-reaching perception. And it further means different things to different people at different points in time $[13,14]$.

The concept of participation is frequently applied by people with varied ideological standpoints, embellished with diverse connotations [15] According to [16] the concept of participation is a philosophically unclear concept that produces a variety of contending applications and connotations. This is corroborated by the assertion of [17] that the upshot in the myriads of definitions is a fallout of array of interpretations on how participation is being defined with respect to what it is likely to achieve, whom it is anticipated to include and how it is to be carried out.

\subsection{Statement of the Problem}

Policy makers and regional analysts are concerned about the decline in participation in rural development activities by the rural people who are being protected by the practice of participatory development. The consequence of this decline in participation of the rural people has led to an all-time high total neglect of the rural areas especially in developing countries like 
Nigeria. Since the overall notion behind rural development is to improve on the quality of lives and well-being of the rural dwellers as regards the social, economic and cultural aspects of their existence.

The development of the rural areas in Nigeria should have been a priority project that transcends the rhetoric of providing incentives for agro-based and natural resource driven approach in rural areas. But in the recent past, successive governments in Nigeria have made fewer attempts for an all-inclusive participation of the government and the people in the stages in the economic planning process. The Nigerian context works the reverse as the public only gets to know the outcome of such decisions after they have been made by policy makers without input from the people. The people are surreptitiously consulted, informed and placated after making antipeople policies which according to [18] model of citizen participation falls within the rung of tokenism.

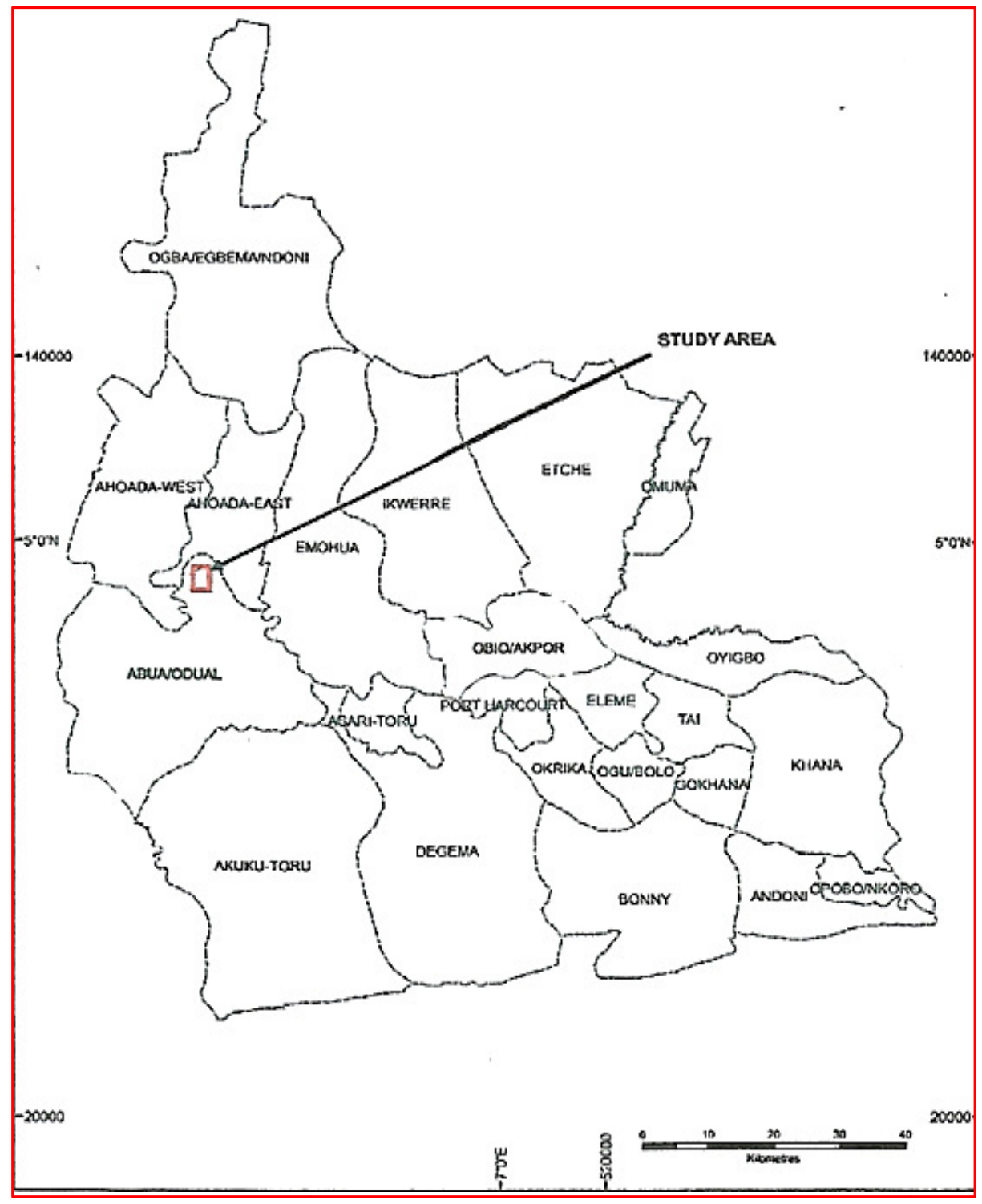

Map of Rivers State showing the study area

Source: Works Department, Abua/Odual Local Government Area, 2016 


\subsection{Research Aim}

The aim of the research is to assess level of participation of communities and community development committees in provision of public infrastructure in selected rural communities of Abua/Odual Local Government Area in Rivers.

\subsubsection{Research objectives}

The objectives of this research are:

a) To identify the existing mechanism for public participation in rural development process in the study area.

b) To ascertain the level of participation in rural development in the selected communities.

c) To ascertain if the Community Development Committee (CDC) in Otari, Omale and Odaga communities participate in the implementation of development projects.

\subsection{Significance of the Research}

This research is envisioned to ascertain the effectiveness of public participation in the development of rural areas. The knowledge gained from this research will enable the government at the local and state levels formulate policies and programs that would encourage effective engagement of the people in decision-making, policy implementation, benefit and evaluation of development programs aimed at improving the standard of living and quality of life of the rural areas.

\section{LITERATURE REVIEW}

\subsection{The Concept of Participation and Its Origin}

Participation is not a static process; it is dynamic in nature and can hardly be measured by any known parameter. Participation originates and shapes experiences of individuals participating in decision-making processes for a collective developmental purpose.

The concept of public participation has in recent times gained momentum but its origin could be traced to the era of the Greek philosopher Aristotle. The intent of Aristotle was to contribute to good life and human happiness with the aim of encouraging people to participate in state affairs to fulfil and develop human disposition.

In the United Kingdom, the concept of public participation according to the [19] has its origin traceable recently to the creation of responsive public services, consumer orientation in the 1980s and community development initiatives in the 1970s.

However, the concept of participation is an enriched all-embracing notion that has various connotations between its definition and application. Its definition depends on the contextual application and the principle being applied at that point in time. Another school of thought views it from the lens of practice and the third school of thought views participation as an end itself [20].

In the rendering of [21] participation is an avenue to educate the citizenry and to intensify their competence in decision-making. It is pertinent to state that the decision-making in this context serves as the driving force used by the citizenry to influence decisions that affect their lives, wellbeing and an in most cases it serves as arena to transfer political power. Participation is "collective efforts to increase and exercise control over resources and institutions on the part of groups and movements of those hitherto excluded from control" [22, p.14].

This definition is skewed towards creating fora that ensure community participation in decisionmaking towards rural development. Also, [23] asserts that 'involvement' would have been more appropriate connotation and seem to be an allembracing concept than participation. And further states that while participation points towards sharing, involvement implies a sense of belonging. Thus, making the definition of public participation as the vigorous contribution of a group of people in the decision-making process through public involvement in the responsiveness of policies through consultations.

The position of [23] on participation was corroborated by [24] who asserts that participation means the 'involvement of intended beneficiaries in the planning, design, implementation and subsequent maintenance of the development intervention. It means that people are mobilized to manage resources and make decisions that affect their lives' (p6). Furthermore, [25] assert that 'community participation indicates an active role for the 
community, leading to significant control over decision' while consultation is taken to mean 'sharing of information but not necessarily power' (p17).

Similarly, [26] assert that community participation entails decision-making in a community development process which enables the communities, families and individuals take up roles that would enable them develop capacities to make meaningful contributions towards their welfare and development.

In the rendering of [27] participation entails the involvement of a people in decision-making process with respect to what would be done for them, how they would be part of the implementation of such decisions reached and the contribution of various resources to participate in specific organization or activities.

Furthermore, [18] asserts that public participation is the process where the public participate at different levels regarding societal goals to exert significant influence over decisions in the allocation of resources towards improving the rural quality of life. However, [18] emphasizes that ladder of public participation is an effective guide for the selection of activities by the public and encourages informed decisions to either reject or accept offered roles and decisions made by organizations the people want to share their control.

There is a nexus in all the definitions and assertions with respect to participation because it points towards the fact that some group of persons are involved in organizing and making decisions for themselves and by themselves. This has made participation a public affair. Since decisions are made by representatives of groups for the generality of the members and in most cases the group dynamics and nuances are put into consideration in ideal situations.

To achieve this there are some inherent objectives of public participation which include:

1. To strengthen the existing interpersonal relationships among members of the group (community).

2. To improve the decision-making process for the people and by the people.

3. To ensure adequate representation of a diversity of social groups in decisionmaking.
4. To aid, elucidate and stabilize effective communication between stakeholders (community) and development agencies and partners.

5. To encourage local ownership, commitment and accountability with respect to community development matters.

6. To understand the group dynamics and nuances in community participation efforts.

\subsection{Rural Development at the Community Level}

One important strategy for effective community participation in rural development efforts involves the congregation of diverse individuals to form a common front within the community. This front encourages community participation and development to commence at the smallest units and expands outwards based on the notion of the proximate law.

Despite efforts geared towards community participation for development of the rural areas, there have been some challenges faced by the local officials, planners and citizens alike. This process is oftentimes mired by limited time for implementation and other resources like finance. In some situations, the feedback process for approval for the continuation and/or stoppage of the development effort could take a while to complete.

Webb and Hatry [28] assert that increase in public participation will lead to increase in the frequency of power struggles encumbering the operations of government in rural development efforts. This often leads to challenges associated with relinquishing power to local authorities in developing the rural areas.

Public participation if not properly monitored can lead to power struggle between local authorities and the public on one side, and within the public groups for the control of policy decisions and development resources in the rural areas.

However, based on the above perceptions and assertions of public participation it is pertinent to state that most of these perceptions hardly ever occur in the global south especially in developing countries like Nigeria. As most rural development programmes are skewed and controlled by the vociferous minorities whose interests are being protected with minimal input from the 
unrepresented majorities who are the beneficiaries.

\section{METHODOLOGY}

The study is a cross-sectional research which adopted multi-stage sampling technique to collect data.

The entire communities in the local government areas were listed to form the sample frame. A purposive sample of one-hundred (100) respondents was drawn from Otari, Omalem and Odaga communities. Selection was based on population, number of households and level of community development programmes. Data was collected using the stratified random sampling technique which involves heads of households, members of Community Development Committees (CDCs) with the aid of close-ended questionnaires. The data were analysed, and results were presented in simple percentages and charts.

Table 1. Distribution of questionnaire in the study area

\begin{tabular}{ll}
\hline Community & No \\
\hline Otari & 69 \\
Omalem & 18 \\
Odaga & 13 \\
Total & $\mathbf{1 0 0}$ \\
\hline \multicolumn{2}{c}{ Source: Authors' field survey, 2016}
\end{tabular}

\section{FINDINGS}

\subsection{Existing Mechanism for Public Participation in Community Development Project}

The findings of the study revealed the existing mechanism put in place to enable members of the communities participate in development projects is based on specific criteria. These criteria for participation include the: age, occupation and level of income of the participant(s) and it is so not just for the study area but for the entire clan. Respondents assert that the age grade system is adopted to enable participation in those communities in the study area. Specific age grade is assigned specific duty to undertake during community development projects. The occupation of individuals also come into focus when participating in community development projects because most of the residents are farmers and traders as such have sufficient funds to contribute towards implementing community development projects. This is also applicable to the income level of the participant(s); more income determines the extent of participation of the individual in the community. See Figs. 1 and 2 .

The occupation of the respondents was ascertained and the data got from field showed that the predominant occupation of the people in the study area is farming with $34 \%$ of the respondents engaged in farming, closely followed by trading with $22 \%$ of the respondents. The fisher folks were represented with $13 \%$ of the respondents and the least were those involved in transportation as their occupation with $3 \%$ of the respondents. These occupation distribution shows the typical rural occupations that people are engaged in to earn a living for themselves. See Fig. 2.

The monthly average household income of the respondents show that $28 \%$ of the respondents earn between $\mathrm{A55}, 001$ - $\mathrm{A} 65,000$, while $20 \%$ of the respondents have an average monthly household income of $\mathbf{A 6 5 , 0 0 0}$ and above and $8 \%$ of the respondents have an average monthly

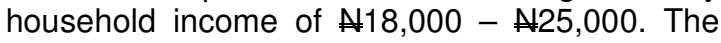
income range shows that the earning power of the greater majority is marginal because most of the community members are agrarian at the subsistence level. Hence the low income. See Fig. 3 for details.

\subsection{Level of Participation in Rural Development Projects}

The dynamics of participation in rural development projects in the study area entails just consultation with stakeholders in the communities. This further determines the stage at which the participant(s) can be involved in community development projects. The consultation is done in stages from the planning, initiation to completion of the project. A selected few members of the communities are actively involved as evidenced in Figs. 3, 4 and 5.

The perception of the level of participation of community members was rated and from the data it was evidenced that respondents were generally satisfied with their level of engagement in community development projects embarked by the community and government alike in Fig. 6 . 


\subsection{Initiation of Development Project}

In the aspect of initiation of development projects in the community, $95 \%$ of the respondents acknowledged that they were consulted before the commencement of some development project and 5\% of the respondents were not consulted hence they did not participate in the process.

However, the residents of the communities and the Community Development Committees members are given opportunities to participate and contribute in most developmental projects at different stages. From the data got, $55 \%$ of the respondents agreed that they were consulted and made inputs at every stage of the project. Also $28 \%$ of the respondents were only consulted at the planning stage while $12 \%$ were involved at the initiation stage and $5 \%$ of the respondents participated at the implementation stage.

The level of participation by members of the communities are based on specific terms on participation; $59 \%$ of the respondents contribute financially, $13 \%$ of the respondents with competence and knowledge in such project participate by helping in the supervision while $19 \%$ of the respondents contribute to a general purse and $9 \%$ of the respondents participate in other areas like conveyance of materials to site, provide security for the materials and the like. This is evident in Fig. 5.

\subsubsection{Spheres of participation}

Based on the spheres of participation by both community members and the community development committees (CDCs) in the study area, respondents were asked to rate the entire process to ascertain their level of satisfaction. The result showed that $44 \%$ of the respondents were very satisfied with the sphere of participation of members of the communities and the community development committee members (CDCs), $36 \%$ of the respondents were satisfied and $10 \%$ of the respondents were neutral. Also $3 \%$ of the respondents were very dissatisfied with the sphere of participation and $7 \%$ were dissatisfied with process and sphere of participation of the community members.

\subsection{The Level of Participation of Community Development Committees (CDCs) in Community Projects}

The members of community development committees (CDCs) in the study area have been proven to have participated in the implementation projects embarked upon by government, community (self-help) and other donor agencies in the community.

From available key informant responses, it is established that the community development committees (CDCs) have limited access to funding and mainly resort to embark on self-help projects like community town halls, in some cases they supervise some of the ongoing government projects within the communities. See Plates $1-3$ and Fig. 6.

The participation levels of the community members are drawn into stages, processes and group specific. Fig. 6 shows the percentage of participation by various groups within the communities. From the available data, the men association as a group participated most in community development programmes. The participation is hierarchical in nature because tasks at various phases of community development programmes are assigned based on Age grade, occupation and income levels. This is closely followed by the Youth association which comprises community and faith based organizations within the communities. The women group most times play the supportive role as the communities are patrilineal and women are limited in participation especially in decisionmaking processes. The Community Development committees (CDCs) as a group plays the supervisory and mediatory roles in the entire project phases.

\section{DISCUSSION}

From the foregoing, there is a fundamental question that has been raised which involves the perception of the rural dwellers. This question revolves around what happens to the negative perceptions of public participation in rural development? If such perception should be treated like every other view or should it be given priority attention as it affects the well-being and health of those that would be affected by the rural development process in their communities. 


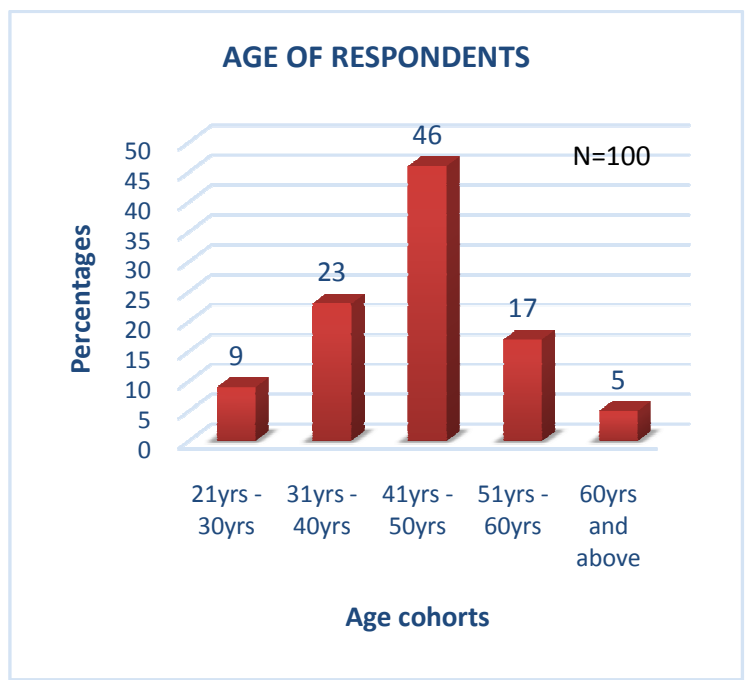

Fig. 1. Age of respondents

Source: Authors' field survey, 2016

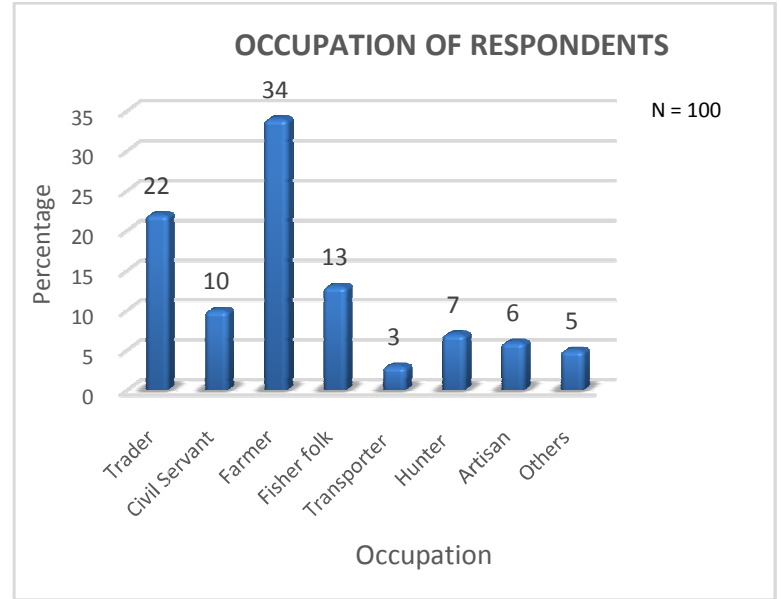

Fig. 2. Occupation of respondents

Source: Authors' field survey, 2016

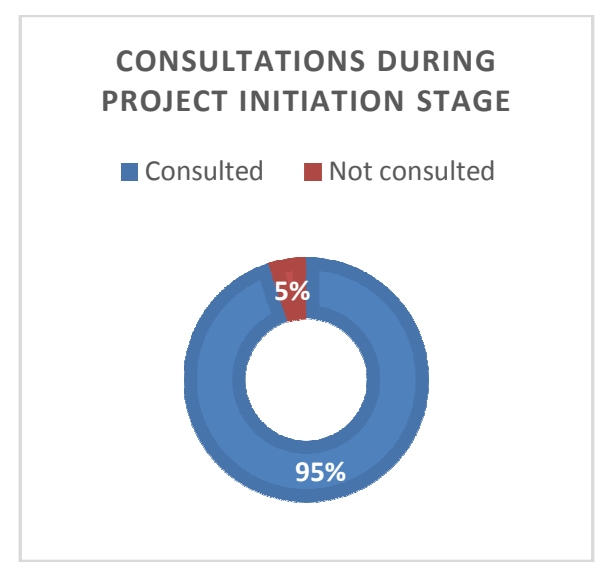

Fig. 3. Consultations during project initiation Source: Authors' field survey, 2016 


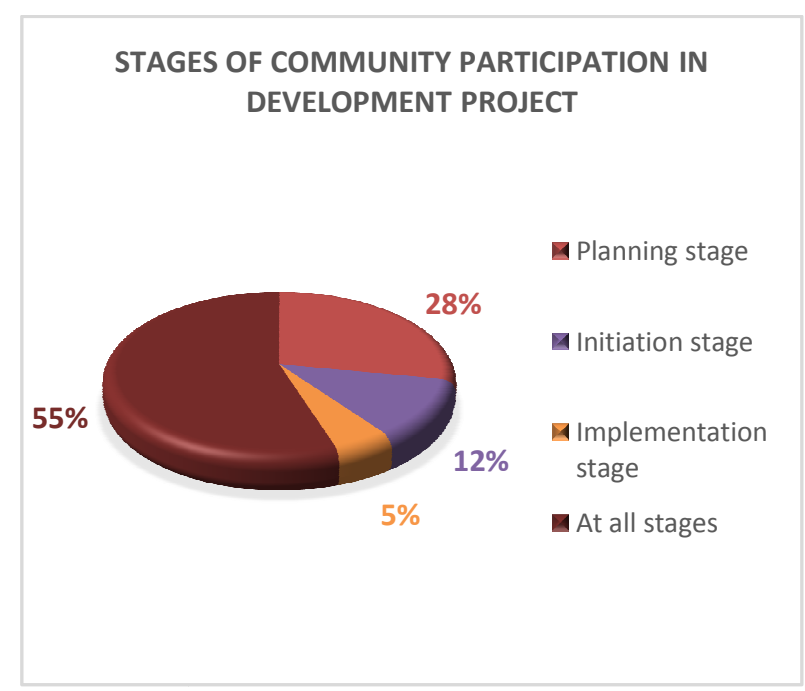

Fig. 4. Community participation in projects Source: Authors' field survey, 2016

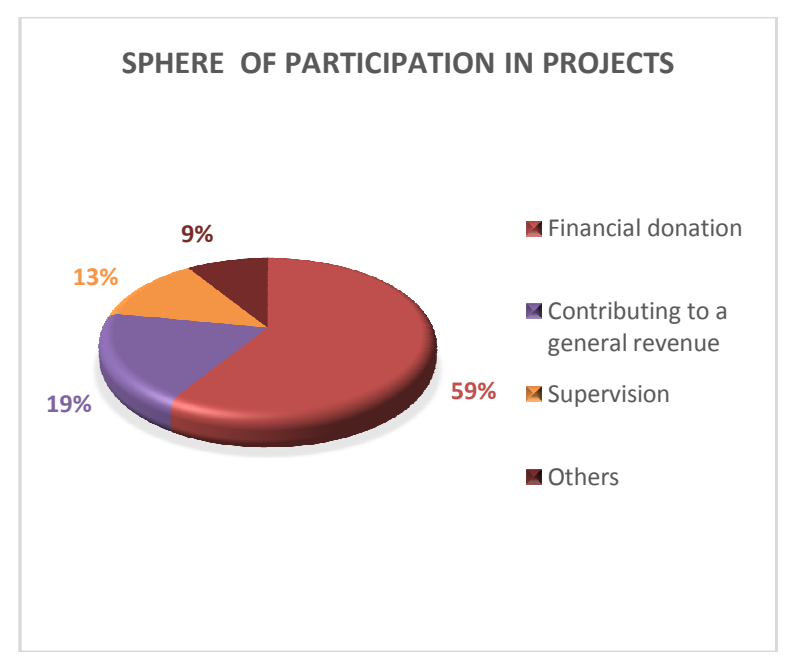

Fig. 5. Level of participation in projects Source: Authors' field survey, 2016

The recent trend in Nigeria is that most states are experiencing rapid urbanization in every dimension especially in population growth and city sprawl which includes Rivers State.

Amid these strides and challenges, rural development planning has been part of the government development process right from the colonial era to modern times as evident in the Masterplans commissioned between 1973 2003 by the then government of Rivers State. These rural development programmes over time have incrementally become very expensive and ambiguous to implement. This has made public participation in rural development planning efforts on paper different from what has been achieved on ground.

It has brought to limelight the gap between actual achievements and the original intentions of such rural development efforts.

However, the identified causes of the gap based on available literature from several studies are hinged on challenges revolving around effective management; technical, financial and organizational structure of rural development planning in Nigeria. 


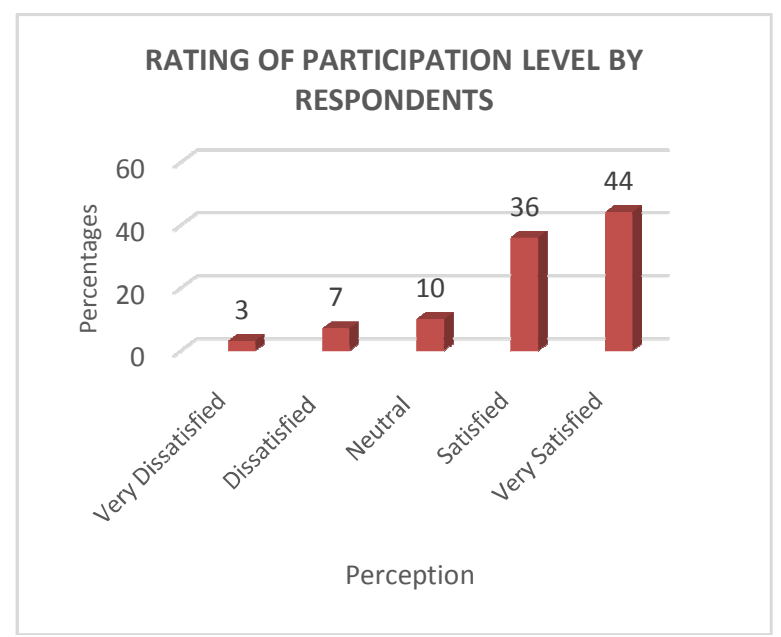

Fig. 6. Respondents rating of participation in projects Source: Authors' field survey, 2016

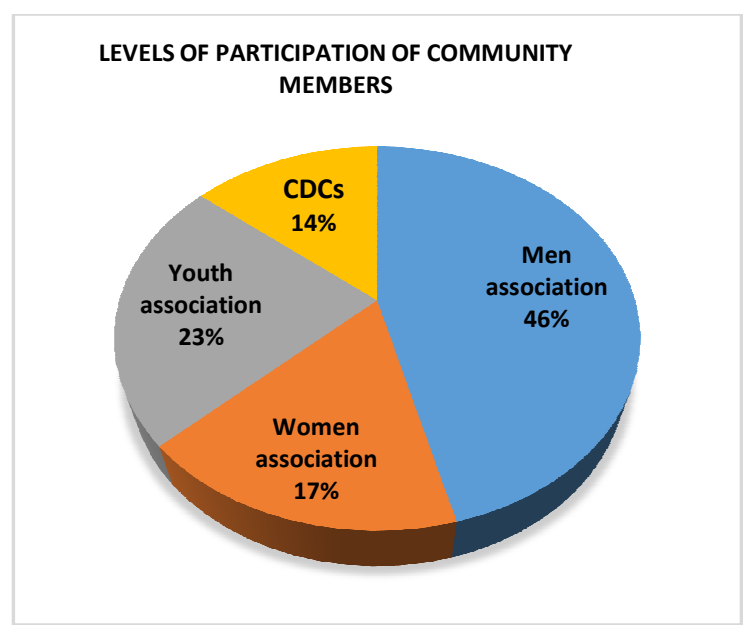

Fig. 7. Levels of community members Source: Authors' field survey, 2016

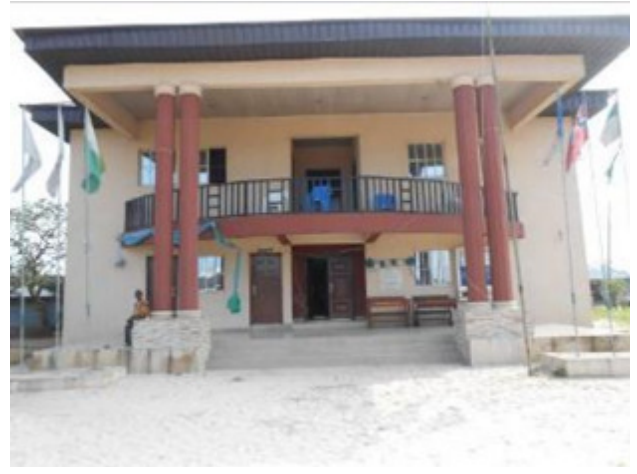

Plate 1. Showing Town Hall Project embarked upon by Community Development Committee (CDC) in Otari community in the study area Source: Authors' field survey, 2016
It is pertinent to state that the development of rural areas in Nigeria is desirable, justified and acknowledged but the onus of implementation lies within the purview of policy makers to do the needful with respect to actions to be taken. This will be successful if the actions taken are devoid of vested interest of policy makers and other power brokers within and outside the system notwithstanding of the impressive stratagems adopted that would encourage the implementation of rural development planning programmes and benefit the rural poor. Without these steps taken, effective public participation in rural development planning will remain very elusive notion in futility and become just another academic exercise on rural development in Nigeria. 


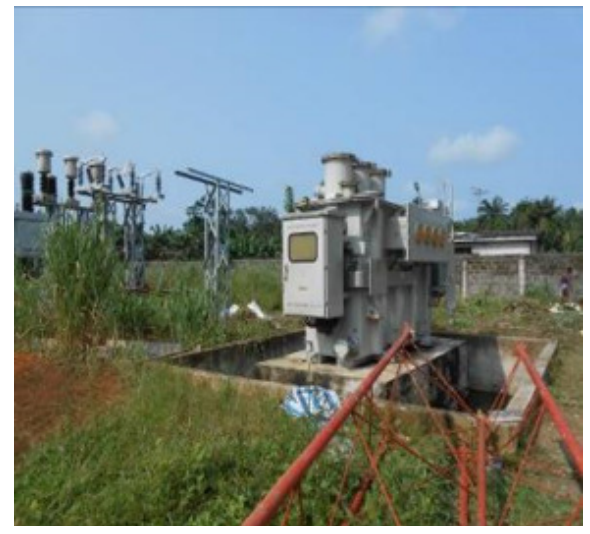

Plate 2. Showing an ongoing Government Power Project in Odaga Community supervised by members of the Community Development Committees (CDCs) Source: Authors' field survey, 2016

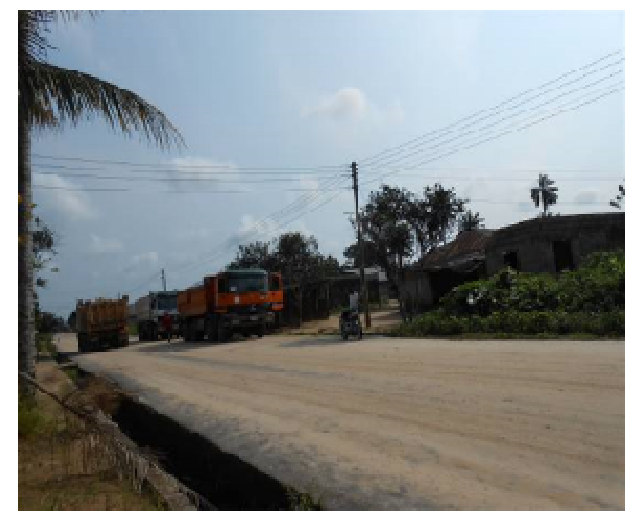

Plate 3. Showing an ongoing road construction project in Otari Community supervised by members of the CDC Source: Authors' field survey, 2016

\section{CONCLUSION}

This research has found out that the level of effectiveness of community participation in development of projects in the study area was based on subjective rating and some objective measures of public participation. These were used to assess the level of participation as got from the responses of the respondents. By observing the relationship between these measures, it is possible to ascertain the level of effective participation in the development of projects of communities in the study area.

The determination of the level of participation effectiveness would facilitate the provision of effective guidelines for future actions and policies in the communities.
It will also enable policy makers to identify and carefully select actions and plans that will achieve specific levels of participation. This will be for the people and government alike in the decision making, implementation, benefits and evaluation of development policies and programmes directed towards improving the general welfare of the communities.

Consultations were made at the community level and most persons were given the opportunity to participate and contribute through community town hall meetings, announcements and proclamations in the communities.

It was also observed in the study that neither the CDCs nor the government was guided by any community development plan which would have served as a policy direction and implementation guide through which all development decisions would have been hinged upon.

Thus, there is the need for the preparation of community development documents (Masterplan) to serve as a blue print to guide development in the communities.

Since there were proper consultations between the people, CDCs, government and donor agencies, respondents were very satisfied with their level of involvement and participation.

Also, the CDCs were far reaching in their composition because part of the criterion for membership into the CDC is based on being a head of household in any of the communities.

\section{RECOMMENDATIONS}

Based on the findings of this research, the following recommendations are necessary:

The importance of an effective information dissemination and management system on the assessment of public participation and its effectiveness in rural development planning programmes should not be downplayed as that would determine how it will be used as feedback mechanism.

There should be proper education of the professionals, public and agencies of government charged with the responsibility of undertaking rural development projects to understand the intricacies of such projects and learn how to make highest and best use of the limited available resources at that 
point in time to improve the rural environment.

There should be proper enlightenment programmes for the need to establish community development committees (CDCs) in the rural areas that would achieve effective public participation in rural development projects and planning.

There should be a proper design and implementation of specific people oriented rural development plans to encourage the community members to participate effectively at all stages of the development.

There should be the establishment of local and/or district planning authority where there is none to exclusively monitor and effectively coordinate most of the rural development processes embarked upon by the government at the community levels to avoid conflict of interest and overlapping functions between government agencies and community development committees (CDCs).

There should be the immediate establishment of state planning board where there is none to oversee activities of the local planning authorities in line with extant laws of the land.

There should be proper needs assessment done before embarking on any rural development programme to avoid unnecessary wastages of scarce resources and construction of 'beautiful nonsense'.

The community development committees (CDCs) should be an integral part of any rural development programme because of their closeness to people and the criteria for their appointment, selection and/or election in most communities.

\section{COMPETING INTERESTS}

Authors have declared that no competing interests exist.

\section{REFERENCES}

1. Nooy ATJ. Modern and endogenous development. Civilization and empowerment. Images and realities of rural life. Van Gorcum, Assen. 1997;107120.
2. Clark J, Jones A, Potter C, Lobley M. Conceptualizing the evolution of the European Union's agri-environment policy: A discourse approach. Environment and Planning. 1997;29(10):1869-1885.

3. Van der Ploeg, Jan Douwe, Renting $H$, Brunori G, Knickel K, Mannion J, Marsden $\mathrm{T}$, et al. Rural development: From practices and policies towards theory. Sociologia Ruralis. 2000;40(4):391-408.

4. Broekhuizen Rv, Klep L, Oostindie H. Renewing the countryside: An atlas with two hundred examples from the dutch rural society; 1997.

5. Jessop B. The governance of complexity and the complexity of governance, revisited. In: Complexity Science and Society Conference, 11-14 September 2005.

6. Buller $\mathrm{H}$. Re-creating rural territories: Leader in France. Sociologia Ruralis. 2000;40(2):190-199.

7. Ray C. Editorial. The EU LEADER programme: Rural development laboratory. Sociologia Ruralis. 2000;40(2):163-171.

8. Shortall S. The Irish rural development paradigm-an exploratory analysis. Economic and Social Review. 1994; 25(3):233.

9. O'Malley E. The pilot programme for integrated rural development 1988-90. Economic and Social Research Institute (ESRI) Research Series; 1992.

10. Buller $\mathrm{H}$, Wright $\mathrm{S}$. Rural development: Problems and policies. Avebury, Aldershot; 1990.

11. Chambers R. Rural development: Putting the last first: Longman London; 1982.

12. Lane J. Non-governmental organizations and participatory development: The concept in theory versus the concept in practice. In 'Power and Participatory Development'; 1995.

13. Kelly D. Community participation in rangeland management: $A$ report for the Rural Industries Research and Development Corporation: RIRDC; 2001.

14. Hussein K. Participatory ideology and practical development: Agency control in a fisheries project, Kariba lake. Power and Participatory Development. Theory and Practice. Intermediate Technology Publications; 1995.

15. Nelson N, Wright S. Participation and power. In 'Power and Participatory Development'. (Ed. S Wright). 
(Intermediate Technology Publications: London); 1995.

16. Pelling M. Participation, social capital and vulnerability to urban flooding in Guyana. Journal of International Development. 1998;10(4):469-486.

17. Agarwal B. Participatory exclusions, community forestry and gender: An analysis for South Asia and a conceptual framework. World Development. 2001; 29(10):1623-1648.

18. Arnstein SR. A ladder of citizen participation. Journal of American Institute of Planners. 1969;35(4):216-224.

19. Cabinet Office, Modernising Government (cmnd 4130), London; 1999.

20. Mundial B. The assault on world poverty: Problems of rural development, education and health: Published for The World Bank by The Johns Hopkins University Press, Baltimore and London; 1975.

21. Brager G, Specht H, Torczyner JL. Community organizing. Columbia University Press; 1987.
22. Westergaard K. People's participation, local government and rural development: The case of West Bengal, India: Centre for Development Research; 1986.

23. Jagannadham V. Development sans participation. Participation in the development process. Jaipur HCM State Institute of Administration; 1979.

24. Price S, Mylius B. Social Analysis and Community Participation; 1991.

25. Sarkissian W, Cook A, Walsh K. The Community Participation in Practice: A Practical Guide (Perth: Institute for Science and Technology Policy); 1997.

26. Oakley P, Marsden D. Approaches to participation in rural development. International Labour office; 1984.

27. Cohen JM, Uphoff NT. Participation's place in rural development: seeking clarity through specificity. World Development. 1980;8(3):213-235.

28. Webb K, Hatry HP. Obtaining Citizen Feedback: The Application of Citizen Surveys to Local Governments; 1973.

(c) 2017 Brown and Wocha; This is an Open Access article distributed under the terms of the Creative Commons Attribution License (http://creativecommons.org/licenses/by/4.0), which permits unrestricted use, distribution, and reproduction in any medium, provided the original work is properly cited.

Peer-review history:

The peer review history for this paper can be accessed here: http://sciencedomain.org/review-history/19588 